\title{
Effect of celery (Apium graveolens) extract on the growth, haematology, immune response and digestive enzyme activity of common carp (Cyprinus
}

\section{carpio).}

\author{
Gamaia Ali Mohamed ${ }^{1}$ (D) Iman Daw Amhamed ${ }^{1}$ (D) Ahmed Alhadi Almabrok ${ }^{1}$ (D) • \\ Abobaker B. Ali Barka ${ }^{1}$ (D) Soner Bilen ${ }^{2}$ (D) Randa Tahir Elbeshti ${ }^{1^{*}}$ (D) \\ ${ }^{1}$ Department of Aquaculture, Institute of Science, Kastamonu University, Kastamonu, Turkey \\ ${ }^{2}$ Department of Aquaculture, Faculty of Fisheries and Aquaculture, Kastamonu University, Kastamonu, Turkey
}

\begin{tabular}{|c|c|}
\hline A RTICLE I N F O & A B S T R A C T \\
\hline Article History: & $\begin{array}{l}\text { In this study, the effect of a dietary supplementation of Apium graveolens on growth performance, digestive } \\
\text { enzyme activities and immune response of juvenile common carp (Cyprinus carpio) were evaluated. C. carpio, }\end{array}$ \\
\hline Received: 06.09.2018 & with an average weight at the beginning of the experiment of $6.5 \pm 0.07 \mathrm{~g}$, were supplemented with a celery (Apium \\
\hline Received in revised form: 04.10 .2018 & graveolens) aqueous methanolic extract at a dose of $0 \%$ (control), $0.1 \%, 0.5 \%$ or $1 \%$ over 45 days. Every 15 days, \\
\hline Accepted: 15.10 .2018 & respiratory burst, lysozyme and myeloperoxidase activity were measured, and at the end of the study, \\
\hline Available online: 01.11 .2018 & haematological responses, growth performance and digestive enzyme activity were investigated. Respiratory burst \\
\hline Keywords: & and myeloperoxidase activity was significantly improved in all treated groups compared with the control group \\
\hline A. graveolens & $\begin{array}{l}(P<0.05) \text {. Lysozyme activity was highest in the } 0.1 \% \text { and } 1 \% \text { extract groups. At the end of the study, the final } \\
\text { weight }(\mathrm{FW}) \text {, weight gain }(\mathrm{WG}) \text { and specific growth rate (SGR) were significantly increased in the } 0.1 \% \text { group }\end{array}$ \\
\hline Common carp & compared with the other groups. The feed concentration ratio was decreased in the $0.1 \%$ and $1 \%$ groups compared \\
\hline Growth & with the control $(P<0.05)$. Haematological parameters were affected by A. graveolens extract intake $(\mathrm{P}<0.05)$. \\
\hline Haematology & The total white and red blood counts, haemoglobin content and haematocrit value were highest in the $0.1 \%$ extract \\
\hline Immune response & group $(P<0.05)$. However, the mean cell volume and mean cell haemoglobin concentration were decreased in \\
\hline Digestive enzymes activity & $\begin{array}{l}\text { the } 0.5 \% \text { group }(P<0.05) \text {. Digestive enzyme activity (trypsin, amylase and lipase) in all experimental groups was } \\
\text { significantly elevated compared with the control }(P<0.05) \text {. These results indicated an immunostimulatory and } \\
\text { growth-promoting effect and increasing digestive enzyme activity of C. carpio supplemented with an A. graveolens } \\
\text { aqueous methanolic extract. }\end{array}$ \\
\hline
\end{tabular}

Please cite this paper as follows:

Mohamed, G.A., Amhamed, I.D., Almabrok, A.A., Barka, A.B.A., Bilen, S., Elbishti, R.T. (2018). Effect of celery (Apium graveolens) extract on the growth, haematology, immune response and digestive enzyme activity of common carp (Cyprinus carpio). Marine Science and Technology Bulletin, 7(2): 51-59.

\footnotetext{
* Corresponding author

E-mail address: randa.beshti@gmail.com (R. T. Elbeshti)
} 


\section{Introduction}

Fishes not only play an important role as food for humans; they have also emerged as major model organisms for different biomedical researches. A number of experiments with several drugs have been conducted on fish (Govind et al., 2012). The common carp (Cyprinus carpio) is one of the most important fish species in aquaculture (Shirali et al., 2012) and is an economically significant fish species that is cultivated mainly in Asia and Europe. The global production of cultivated C. carpio comprised about $6.14 \%$ of global aquaculture production (FAO, 2008). It is also cultivated commercially (Cao et al., 2013) in other parts of the world such as Australia and South America because of its fast growth rate, facile cultivation and high feed efficiency ratio (Tokur et al., 2006). C. carpio has an important place in Turkey's fishing industry, and the species is widespread throughout Turkey's freshwater ecosystems, such as lakes, ponds and dam lakes (Güner et al., 2014). Compared with other aquaculture species such as shrimp and salmon, carp are considered an eco-friendly fish because most are omnivorous filter feeders and hence consume less fish meal and fish oil than other species (Xu et al., 2014).

Herbs and medicinal plants have a variety of properties, such as an appetite stimulator, growth promoter, antiparasitic, antimicrobial, immunostimulating and antioxidant due to the presence of various active compounds, like flavonoids, alkaloids, phenolics, pigments, steroids, terpenoids and essential oils (Citarasu, 2010). Celery (Apium graveolens) belongs to the Apiaceae and is a widely used food item. It is found in North and South America, Southern Europe, Africa and Asia (Sowbhagya, 2014). Many studies have revealed some pharmacological effects of A. graveolens extracts that were related to their antioxidant (Li et al., 2014), hepatoprotective (Ahmed et al., 2002), anti-inflammatory (Baananou et al., 2012), anticancer, analgesic, antibacterial and anti-spasmodic properties (Modaresi et al., 2012). Its major active constituents are phenolic compounds, flavonoids and volatile oils that can be extracted from its roots, leaves and seeds (Aydemir and Becerik, 2011; Baananou et al., 2012; Li et al., 2014).

The process of digestion determines the accessibility of nutrients needed for all bodily functions and enzymatic activity, and it is the basic tool used to observe feeding acceptability and its contribution towards fish growth and maintenance (Gisbert et al., 2009). Metabolic adaptations to changing feed ingredients and in turn enzymatic secretions result in better feed utilisation (Caruso et al., 2009). Digestive enzyme activities vary in different fish species, which may be due to differences in digestive potential and feeding habits.

The purpose of this study was to investigate the effect of an $A$. graveolens extract on growth performance, haematological profile, immune response and activity of digestive enzymes for C. carpio.

\section{Material and Methods}

\section{Fish and Experimental Design}

C. carpio with an average initial body weight of $6.5 \pm 0.07 \mathrm{~g}$ were obtained from a commercial fish farm in Antalya, Turkey. Fish were transported to the Faculty of Fisheries, Kastamonu University, Turkey. A total of 480 fish were used for this study, and they were randomly divided into four main groups with triplicates per group (12 aquariums) and 40 fish in each aquarium. Fish were acclimatised for 2 weeks before the experiment started. During acclimation, fish were fed a commercial diet twice a day. During the experimental period, fish were fed the commercial diet supplemented with A. graveolens aqueous methanolic extract at a concentration of $0 \%$ (control), $0.1 \%$, $0.5 \%$ and $1 \%$ for $45 \mathrm{~d}$ to satiation twice a day. Fish were maintained under a natural photoperiod ( $12 \mathrm{~h}$ dark/12 h light), and dissolved oxygen ranged from 6.8 to $7.2 \mathrm{mg} / \mathrm{L}$ (Hache Lange), $\mathrm{pH}$ from 7.7 to 8.5 and water temperature from 25 to $28^{\circ} \mathrm{C}$. These parameters were checked daily and were within the accepted range throughout the experimental period.

\section{Preparation of A. graveolens Extract}

A. graveolens was collected from Kastamonu province in the north of Turkey. Leaves were extracted by using an aqueous methanol extraction method according to Pakravan et al. (2012) with some modification as follows. Leaves were ground to a fine powder in a mechanical grinder, and $50 \mathrm{~g}$ samples were added to $1 \mathrm{~L}$ of $40 \%$ methanol (Sigma-Aldrich). The mixture was allowed to stand at room temperature for 3 day and was shaken every day. After $3 \mathrm{~d}, A$. graveolens extract was filtered through filter paper (Whatman filter No 1 ), and the filtrate was collected and evaporated in a rotary evaporator at $55-65^{\circ} \mathrm{C}$ to remove the methanol. The final product was dissolved in distilled water and kept in a flask at $4^{\circ} \mathrm{C}$ for the experimental tests (Bilen et al., 2016). The final extract of A. graveolens after the evaporation process was diluted in $50 \mathrm{~mL}$ of distilled water and then sprayed on the fish diet at concentrations of $0.1 \%, 0.5 \%$ and $1 \%$. The experimental diets were kept in sealed plastic containers and stored at $-20^{\circ} \mathrm{C}$ until use.

\section{Sample Collection}

On days 15, 30 and 45 of the study, three fish from each experimental aquarium were randomly chosen, anaesthetised with $0.30 \mathrm{~mL} \mathrm{~L}^{-1}$ phenoxyethanol, individually weighed and samples were collected. Kidney tissues were collected and transferred individually to 1.5 mL RPMI-1640 medium (Invitrogen, Carlsbad, CA, USA) for direct immunological assays. Blood samples were collected from the caudal vein by heparinised syringes in EDTA tubes to test haematological parameters directly. Blood samples were only collected on day 45 of the feeding trial. Similarly, intestine samples were only collected on day 45 of the feeding trial. These samples were cleaned of waste and all visible fat and stored at $-80^{\circ} \mathrm{C}$ for a digestive enzymes assay. 


\section{Estimation of Growth Parameters}

Fish were weighed at the beginning and end of the study. Growth performance was calculated following the equations of Tekinay and Davies (2001).

$W G(\%)=100 \times \frac{\text { Final fish weight }- \text { Initial fish weight }}{\text { Initial fish weight }}$

$S G R=100 \times \frac{\ln (\text { final fish weight })-\ln (\text { Initial fish weight })}{\text { Experimental days }}$

$F C R=\frac{\text { Feed Intake }(g)}{W G(g)}$

$S R(\%)=100 \times\left[\frac{\text { Final Number of Fish }}{\text { Initial Number of Fish }}\right]$

In these formulae, WG indicates weight gain, SGR indicates specific growth rate in percent weight for each day, FCR indicates feed conversion ratio, and SR indicates survival rate.

\section{Haematological Parameters Analysis}

White blood cell $\left(\mathrm{WBC} \times 107 / \mathrm{mm}^{-3}\right)$ and red blood cell $(\mathrm{RBC} \times$ $\left.106 / \mathrm{mm}^{-3}\right)$ counts and haemoglobin $\left(\mathrm{Hb}, \mathrm{g} / \mathrm{dL}^{-1}\right)$ and haematocrit (Hct, \%) were measured according to methods described by Blaxhall and Daisley (1973). Blood indices included mean cell volume (MCV, $\mathrm{fL})$, mean cell $\mathrm{Hb}(\mathrm{MCH}, \mathrm{pg})$ and the mean cell $\mathrm{Hb}$ concentration (MCHC, \%) were calculated according to the formulae of Lewis et al. (2006).

\section{Immunological Parameters}

Head kidney cells were isolated from freshly euthanized C. carpio according to Kono et al. (2012) with slight modification. Briefly, head kidney tissue was removed carefully and gently pushed through a 100 $\mu \mathrm{m}$ nylon mesh (John Stanier, Whitefield, Manchester, UK) with RPMI-1640 medium supplemented with 5\% foetal bovine serum (Invitrogen) and a $1 \%$ solution of $10,000 \mathrm{~g} \mathrm{~mL}^{-1}$ streptomycin $+10,000$ $\mathrm{U} \mathrm{mL}^{-1}$ penicillin (Invitrogen) and then pushed again through a $40 \mu \mathrm{m}$ nylon mesh cell strainer (Becton, Dickinson and Company, Franklin Lakes, NJ, USA). The final homogenised volume of $3 \mathrm{~mL}$ was placed in a falcon tube. Head-kidney cell suspensions were pelleted by centrifugation at $1800 \mathrm{rpm}$ for $3 \mathrm{~min}$ at $4^{\circ} \mathrm{C}$. After centrifugation, the supernatant was collected to measure myeloperoxidase (MPO) by using 3,3,5,5-teteramethylbenzidine hydrochloride (Sigma-Aldrich) as a substrate (Sahoo et al., 2005) and to measure lysozyme by using a lyophilised Micrococcus lysodeikticus bacterial cell (Sigma-Aldrich) solution as a substrate (Bilen et al., 2014). The pellet was resuspended with $1 \mathrm{~mL}$ of the same medium to assay respiratory burst activity, which was determined by the reduction of nitroblue tetrazolium (Sigma-Aldrich) as a substrate, according to the methods described by Biswas et al. (2013).

\section{Digestive Enzymes Activity}

The intestine was homogenised by a Potter Elvenhjem homogeniser in cold double-distilled water $(0.1 \mathrm{~g} / 1 \mathrm{~mL})$ and centrifuged at $9000 \mathrm{rpm}$ for $20 \mathrm{~min}$ at $4^{\circ} \mathrm{C}$. The resultant supernatant was removed and stored at $-80^{\circ} \mathrm{C}$ to test for digestive enzymes activity as follows. Trypsin activity was determined following the method of Erlanger et al. (1961) using benzoyl-dl-arginine-p-nitroanilide (Sigma-Aldrich) as a substrate. Amylase activity was determined by using $2 \%$ starch (Sigma-Aldrich) as a substrate according to Worthington (1991). Lipase activity was determined by hydrolysis of 4-nitrophenyl myristate (Sigma-Aldrich) according to the method described by Gawlicka et al. (2000). The protein content was evaluated following the method of Bradford (1976).

\section{Statistical analysis}

The result was analysed using SPSS software. One-way ANOVA and Duncan's multiple range tests were used to determine the significant differences between the groups. All results are expressed as mean $\pm \mathrm{SD}$, and $P<0.05$ was considered statistically significant.

\section{Results}

Growth indices of the different groups are presented in Table 1. A significant increase in final weight, WG and SGR was observed for fish supplemented with $0.1 \%$ A. graveolens extract compared with the control $(P<0.05)$, whereas FCR of the $0.1 \%$ and $1 \%$ A. graveolens extract groups was significantly decreased compared with the control $(P<0.05)$. On the other hand, no significant differences were detected in final weight, WG, SGR and survival in the other treatment groups compared with the control group $(P<0.05)$.

Table 1. Growth performance of Cyprinus carpio supplemented with different concentrations of Apium graveolens extract for 45 days.

\begin{tabular}{lcrrr}
\hline \multirow{2}{*}{ Parameters } & \multicolumn{4}{c}{ Groups } \\
\cline { 2 - 5 } & \multicolumn{1}{c}{ Control } & \multicolumn{1}{c}{$\mathbf{0 . 1 \%}$} & \multicolumn{1}{c}{$\mathbf{0 . 5 \%}$} & \multicolumn{1}{c}{$\mathbf{1 \%}$} \\
\hline IW (g) & $6.49 \pm 0.05^{\mathrm{a}}$ & $6.54 \pm 0.03^{\mathrm{a}}$ & $6.58 \pm 0.02^{\mathrm{a}}$ & $6.47 \pm 0.01^{\mathrm{a}}$ \\
FW (g) & $9.67 \pm 0.45^{\mathrm{a}}$ & $10.69 \pm 0.16^{\mathrm{b}}$ & $9.69 \pm 0.02^{\mathrm{a}}$ & $9.64 \pm 0.49^{\mathrm{a}}$ \\
WG (\%) & $49.07 \pm 5.90^{\mathrm{a}}$ & $63.57 \pm 1.82^{\mathrm{b}}$ & $47.38 \pm 0.64^{\mathrm{a}}$ & $48.91 \pm 7.27^{\mathrm{a}}$ \\
FCR & $2.04 \pm 0.03^{\mathrm{a}}$ & $1.48 \pm 0.17^{\mathrm{b}}$ & $1.98 \pm 0.01^{\mathrm{a}}$ & $1.80 \pm 0.05^{\mathrm{c}}$ \\
SGR (\%/day) & $0.89 \pm 0.09^{\mathrm{a}}$ & $1.09 \pm 0.02^{\mathrm{b}}$ & $0.86 \pm 0.02^{\mathrm{a}}$ & $0.88 \pm 0.12^{\mathrm{a}}$ \\
SR (\%) & $91.25 \pm 3.75^{\mathrm{a}}$ & $80 \pm 6.75^{\mathrm{a}}$ & $73.75 \pm 3.05^{\mathrm{a}}$ & $88.75 \pm 1.77^{\mathrm{a}}$ \\
\hline
\end{tabular}

Note: Values are means \pm SE. Different letters in the same line indicate significant differences among groups $(P<0.05)$.

The results indicate that fish supplemented with $0.1 \% A$. graveolens extract had a significant increase in WBC, RBC, $\mathrm{Hb}$ and $\mathrm{Hct}$ and a decrease in $\mathrm{MCV}, \mathrm{MCH}$ and $\mathrm{MCHC}$ compared with the control $(\mathrm{P}<0.05)$. Fish supplemented with $0.5 \%$ A. graveolens extract had a significant decrease in all haematological parameters $(P<0.05)$ except WBC count, which was not significantly different from control fish. Significantly higher WBC count and lower Hct, MCV and MCHC values $(P<0.05$ were observed in blood samples of fish supplemented with $1 \%$ A. graveolens extract, whereas no significant differences were observed for $\mathrm{RBC}, \mathrm{Hb}$ and $\mathrm{MCH}$ compared with the control group.

Immunostimulatory effects of $A$. graveolens extract is provided in Tables 3, 4 and 5. Respiratory burst and MPO activities of fish supplemented with different concentrations of $A$. graveolens extract were significantly elevated $(P<0.05)$ on days 15,30 and 45 compared 
with the control group. The lysozyme level on day 15 was only significantly decreased $(P<0.05)$ in the $0.5 \%$ extract group compared with the control. On day 30 , fish supplemented with $0.1 \%$ or $1 \% A$. graveolens extract showed a significant increase in lysozyme activity $(P$ $<0.05)$. There was no significant difference in lysozyme levels among all groups on day 45 .

Table 2. Haematological profile of Cyprinus carpio supplemented with different concentrations of Apium graveolens extract for 45 days.

\begin{tabular}{lrrrr}
\hline \multirow{2}{*}{ Parameters } & \multicolumn{4}{c}{ Groups } \\
\cline { 2 - 5 } & \multicolumn{1}{c}{ Control } & \multicolumn{1}{c}{$\mathbf{0 . 1 \%}$} & \multicolumn{1}{c}{$\mathbf{0 . 5 \%}$} & \multicolumn{1}{c}{$\mathbf{1 \%}$} \\
\hline WBC $\left(\times 10^{7}\right.$ cells mm $\left.{ }^{-3}\right)$ & $32 \pm 1.41^{\mathrm{a}}$ & $54 \pm 1.42^{\mathrm{b}}$ & $33 \pm 1.40^{\mathrm{a}}$ & $48 \pm 0.89^{\mathrm{c}}$ \\
$\mathrm{RBC}\left(\times 10^{6}\right.$ cells mm $\left.^{-3}\right)$ & $1.35 \pm 0.06^{\mathrm{a}}$ & $1.63 \pm 0.04^{\mathrm{b}}$ & $1.24 \pm 0.02^{\mathrm{c}}$ & $1.34 \pm 0.03^{\mathrm{a}}$ \\
$\mathrm{Hb}\left(\mathrm{g} \mathrm{dl}^{-1}\right)$ & $5.48 \pm 0.28^{\mathrm{a}}$ & $6.55 \pm 0.19^{\mathrm{b}}$ & $4.35 \pm 0.18^{\mathrm{c}}$ & $5.25 \pm 0.19^{\mathrm{a}}$ \\
$\mathrm{Hct}(\%)$ & $19.90 \pm 1.25^{\mathrm{a}}$ & $23.30 \pm 1.20^{\mathrm{b}}$ & $13.62 \pm 1.34^{\mathrm{c}}$ & $18.50 \pm 0.39^{\mathrm{d}}$ \\
$\mathrm{MCV}(\mathrm{fl})$ & $152.95 \pm 1.79^{\mathrm{a}}$ & $142.82 \pm 1.42^{\mathrm{b}}$ & $134.45 \pm 2.42^{\mathrm{c}}$ & $145.77 \pm 1.51^{\mathrm{d}}$ \\
$\mathrm{MCH}(\mathrm{pg})$ & $42.13 \pm 1.69^{\mathrm{a}}$ & $37.12 \pm 1.93^{\mathrm{b}}$ & $34.07 \pm 1.72^{\mathrm{c}}$ & $42.90 \pm 1.81^{\mathrm{a}}$ \\
$\mathrm{MCHC}(\%)$ & $286.17 \pm 3.43^{\mathrm{a}}$ & $273.83 \pm 2.64^{\mathrm{b}}$ & $264.33 \pm 2.16^{\mathrm{c}}$ & $276.50 \pm 1.87^{\mathrm{b}}$ \\
\hline
\end{tabular}

Note: Values are means \pm SE $(n=9)$. Different letters in the same line indicate significant differences among groups $(P<0.05)$.

Table 3. Respiratory burst activity of kidney leucocytes in Cyprinus carpio supplemented with different concentrations of Apium graveolens extract for 45 days.

\begin{tabular}{llll}
\hline \multirow{2}{*}{ Groups } & \multicolumn{3}{c}{ Study period } \\
\cline { 2 - 4 } & $\mathbf{1 5}$ day & $\mathbf{3 0}$ day & $\mathbf{4 5}$ day \\
\hline Control & $1.33 \pm 0.02^{\mathrm{a}}$ & $0.73 \pm 0.02^{\mathrm{a}}$ & $0.86 \pm 0.04^{\mathrm{a}}$ \\
$0.1 \%$ & $1.44 \pm 0.03^{\mathrm{b}}$ & $1.64 \pm 0.03^{\mathrm{b}}$ & $1.14 \pm 0.07^{\mathrm{b}}$ \\
$0.5 \%$ & $1.54 \pm 0.05^{\mathrm{c}}$ & $1.55 \pm 0.03^{\mathrm{c}}$ & $1.27 \pm 0.06^{\mathrm{c}}$ \\
$1 \%$ & $1.47 \pm 0.09^{\mathrm{b}}$ & $1.02 \pm 0.02^{\mathrm{d}}$ & $1.30 \pm 0.05^{\mathrm{c}}$ \\
\hline
\end{tabular}

Note: Values are means $\pm S E(n=9)$. Different letters in the same column indicate significant differences among groups $(P<0.05)$.

Table 4. Myeloperoxidase activity in kidney leucocytes of Cyprinus carpio supplemented with different concentrations of Apium graveolens extract for 45 days.

\begin{tabular}{lccc}
\hline \multirow{2}{*}{ Groups } & \multicolumn{3}{c}{ Study period } \\
\cline { 2 - 4 } & $\mathbf{1 5}$ day & $\mathbf{3 0}$ day & $\mathbf{4 5}$ day \\
\hline Control & $201.20 \pm 1.64^{\mathrm{a}}$ & $203.11 \pm 2.67^{\mathrm{a}}$ & $196.59 \pm 2.14^{\mathrm{a}}$ \\
$0.1 \%$ & $213.67 \pm 2.83^{\mathrm{b}}$ & $365.05 \pm 3.02^{\mathrm{b}}$ & $224.18 \pm 2.58^{\mathrm{b}}$ \\
$0.5 \%$ & $221.95 \pm 1.71^{\mathrm{c}}$ & $235.11 \pm 3.34^{\mathrm{c}}$ & $202.04 \pm 2.69^{\mathrm{c}}$ \\
$1 \%$ & $239.69 \pm 0.99^{\mathrm{d}}$ & $305.18 \pm 3.21^{\mathrm{d}}$ & $237.06 \pm 1.97^{\mathrm{d}}$ \\
\hline
\end{tabular}

Note: Values are means $\pm S E(n=9)$. Different letters in the same column indicate significant differences among groups $(P<0.05)$.

Table 5. Lysozyme activity of kidney leucocytes in Cyprinus carpio supplemented with different concentrations of Apium graveolens extract for 45 days.

\begin{tabular}{llcl}
\hline \multirow{2}{*}{ Groups } & \multicolumn{3}{c}{ Study period } \\
\cline { 2 - 4 } & $\mathbf{1 5}$ day & $\mathbf{3 0}$ day & $\mathbf{4 5}$ day \\
\hline Control & $0.31 \pm 0.02^{\mathrm{a}}$ & $0.31 \pm 0.02^{\mathrm{a}}$ & $0.35 \pm 0.05^{\mathrm{a}}$ \\
$0.1 \%$ & $0.31 \pm 0.01^{\mathrm{a}}$ & $0.34 \pm 0.01^{\mathrm{b}}$ & $0.34 \pm 0.03^{\mathrm{a}}$ \\
$0.5 \%$ & $0.30 \pm 0.01^{\mathrm{b}}$ & $0.32 \pm 0.02^{\mathrm{a}}$ & $0.33 \pm 0.02^{\mathrm{a}}$ \\
$1 \%$ & $0.31 \pm 0.01^{\mathrm{a}}$ & $0.34 \pm 0.02^{\mathrm{b}}$ & $0.35 \pm 0.04^{\mathrm{a}}$ \\
\hline
\end{tabular}

Note: Values are means $\pm S D(n=12)$. Different letters in the same column indicate significant differences among groups $(P<0.05)$.

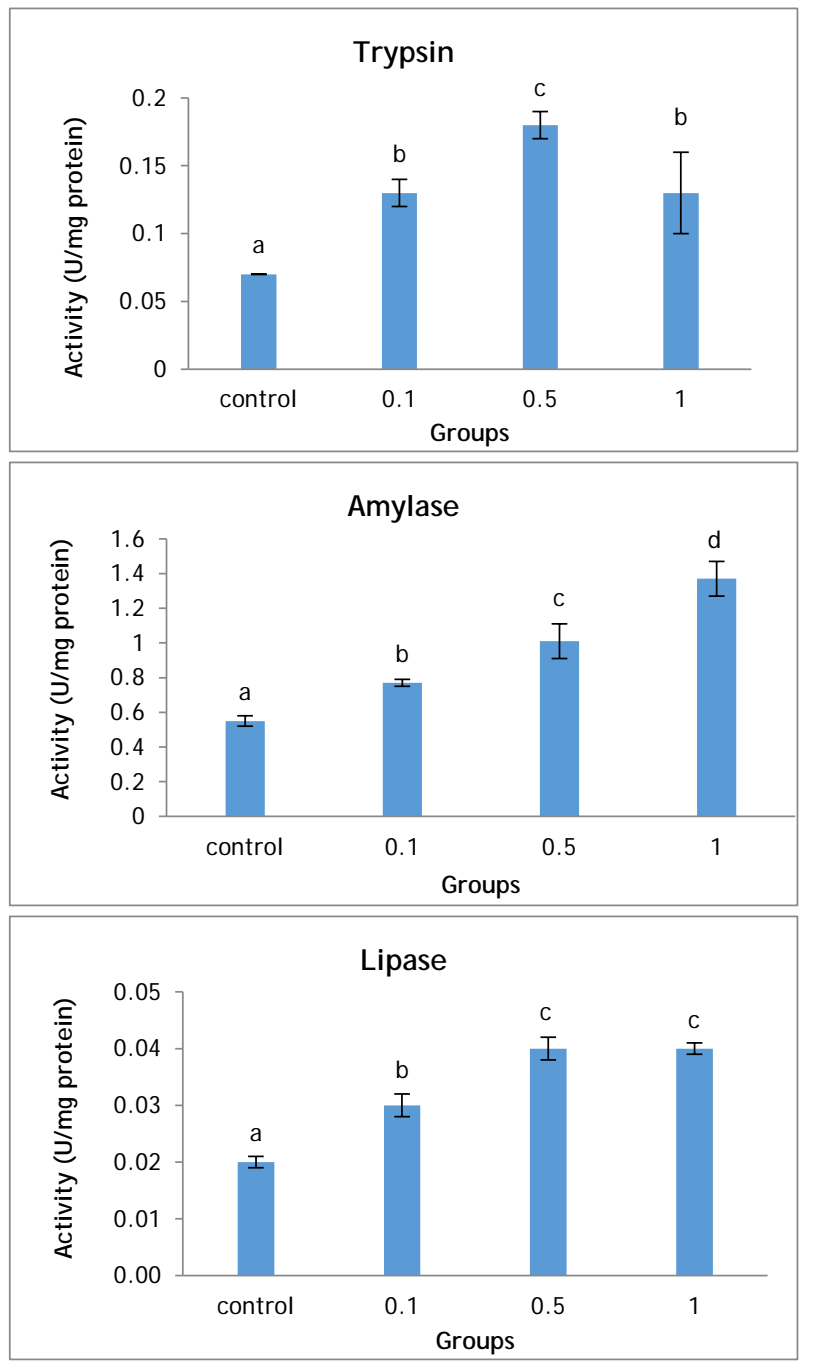

Figure 1. Activity of trypsin, amylase and lipase in the intestines of Cyprinus carpio fed a basal diet (control) and supplemented with different concentrations of Apium graveolens extract. Different superscript letters indicate significant differences among groups $(P<$ $0.05)$. 
Digestive enzyme levels are shown in Figure 1. The activity of trypsin, amylase and lipase in fish intestines increased significantly when fish were supplemented with $0.1 \%, 0.5 \%$ or $1 \%$ A. graveolens extract compared with control group $(P<0.05)$ (Figure 1).

\section{Discussion}

Medicinal plant products are used as a growth promoter, antistress, appetite stimulator, immunostimulant and as a tonic and are said to have aphrodisiac and antimicrobial characteristics in finfish and shrimp larviculture due to the activities of flavonoids, alkaloids, phenolics, pigments, steroids, terpenoids and necessary oils (Sivaram et al., 2004). In this study, supplementation with A. graveolens extract changes the growth parameters in C. carpio (Table 1). However, the final weight, WG and SGR were elevated and a better FCR was obtained in fish supplemented with $0.1 \%$ extract. Similarly, OlveraNovoa et al. (1990) reported that WG, SGR, nitrogen deposition and feed intake in Mozambique tilapia (Oreochromis mossambicus, Peters) were better when supplemented with low levels (i.e. 15-20\%) of alfalfa protein. Also, WG was significantly improved when Japanese flounder (Paralichthys olivaceus, Temminck \& Schlegel) were supplemented with a $0.5 \%$ herbal mixture (Seung-Cheol et al., 2007). Most probably, fat was used for energy and protein was used for growth in the herbal supplement diet (Yilmaz et al., 2012). Mostafa et al. (2009) fed Nile tilapia fingerlings a basal diet containing $0,0.5,1$ and $1.5 \mathrm{~g} / 100 \mathrm{~g}$ fenugreek (Trigonella foenum graecum) seed meal for 12 weeks and found that the use of $1 \mathrm{~g} / 100 \mathrm{~g}$ fenugreek seed meal improved fish performance. According to Farahi et al. (2012), dietary Aloe vera supplementation was not efficient in promoting growth performance of rainbow trout (Oncorhynchus mykiss). Yilmaz et al. (2012) reported that WG, FCR and SGR of sea bass (Dicentrarchus labrax) were not affected by a $1 \%$ rosemary (Rosmarinus officinalis) and $T$. foenum graecum supplementation. Also, the growth rate of koi carp (Cyprinus carpio) was not affected by a dietary supplementation of tetra (Cotinus coggygria) (Bilen et al., 2013). However, some herbs have positive and promoting effects on fish growth (Xie et al., 2008; Mahdavi et al., 2013).

Haematological assays may provide an index of the physiological status of fish. WBC, $\mathrm{RBC}$ count, $\mathrm{Hb}$ and $\mathrm{Hct}$ are particularly recommended as tests that could be performed on a routine basis in fish farms to monitor the health of the stock (Haghighi and Rohani, 2013). The present study indicated that $C$. carpio supplemented with $0.1 \%$ A. graveolens extract showed an increase in $\mathrm{WBC}, \mathrm{RBC}, \mathrm{Hb}$ and Hct and a decrease in $\mathrm{MCV}, \mathrm{MCH}$ and $\mathrm{MCHC}$ compared with the control group. When supplemented with $0.5 \%$ A. graveolens extract, a significant decrease in all haematological parameters was observed, except WBC count that showed no significant change compared with the control. De Pedro et al. (2005) indicated that total and differential WBC counts are important indices of non-specific defence activities in fish. Also, they are centrally involved in phagocytic and immune responses to bacterial, viral and parasitic challenges (Houston, 1990). Similarly, O. mykiss supplemented with a powdered ginger (Zingiber officinale) rhizome for 12 weeks showed an increase WBC, RBC, Hb and Hct values (Haghighi and Rohani, 2013). Also, it was reported that
WBC and RBC counts and $\mathrm{Hb}$ value were higher in Indian catfish (Mystus montanus) fingerlings supplemented with an herbal diet when compared with the control (Kumar et al., 2014). Other investigators reported that there were no significant differences in RBC and Hct in C. carpio supplemented with dietary A. vera (Alishahi et al., 2010), or RBC and Hb in O. mykiss (Farahi et al., 2012) or all haematological parameters in O. mykiss (Haghighi et al., 2014).

Phagocytosis and the respiratory burst response by phagocytes in blood and tissues represent a major antibacterial defence mechanism in fish (Secombes, 1996). Respiratory burst activity measured by nitroblue tetrazolium is one of the most important bactericidal mechanisms in fish (Secombes and Fletcher, 1992). In this study, respiratory burst activity of fish supplemented with different concentrations of A. graveolens extract were significantly elevated $(P<$ 0.05 ) on days 15,30 and 45 compared with the control group. A similar result was observed by Bilen et al. (2011) when O. mykiss was supplemented with dietary C. coggygria leaves. Harikrishnan et al. (2010) reported a significant increase in respiratory bursts at 50 and 100 doses in olive flounder supplemented with three Korean plants. Haghighi and Rohani (2013) reported that respiratory burst activity was significantly high in O. mykiss fed a commercial diet containing $Z$. officinale. Also, our results are in agreement with those of some studies of dietary immunostimulants used in various fish species (Yin et al., 2009; Bilen and Bulut, 2010).

Neutrophils contain MPO in their cytoplasmic granules (Rodriguez et al., 2003). MPO is an important enzyme with microbiocidal properties, which utilises an oxidative radical $\left(\mathrm{H}_{2} \mathrm{O}_{2}\right)$ to produce hypochlorous acid (Dalmo et al., 1997). This process is believed to be important in killing microorganisms (Johnston, 1978). This study revealed an increase in MPO content in all experimental groups. In line with our study, O. mykiss supplemented with $1 \%$ of quercetin and $1 \%$ black cumin seed (Nigella sativa) oil showed a significant increase in MPO activity (Awad et al., 2013). Heart-leaved moonseed (Tinospora cordifolia) leaves also increased MPO activity in O. mossambicus (Alexander et al., 2010). Bilen et al. (2013) also reported similar results with the administration of C. coggygria extract.

Lysozyme activity is an important component in the immune system of fish. Lysozyme is an important enzyme in the blood that actively lyses bacterial cell wall peptidoglycans. It is also known to act as an opsonin and activates the complement system and phagocytes (Magnadottir, 2006). In this study, the lysozyme level on day 15 was significantly decreased in the $0.5 \%$ extract group. On day 30 , fish supplemented with $0.1 \%$ or $1 \%$ extract showed a significant increase in lysozyme activity, there was no significant difference among the groups on day 45. The observed increasing in lysozyme level is in agreement with several reports on the role of herbal immunostimulants in enhancing lysozyme activity (Rao et al., 2006; Choi et al., 2008; Bilen et al., 2011). Moreover, Tang et al. (2014) recorded an elevation in lysozyme activity in $O$. niloticus supplemented with a Chinese herbal mixture of angelica, astragalus, liquorice root, honeysuckle and hawthorn. On the other hand, Sivaram et al. (2004) noticed no significant change in lysozyme activity in 
juvenile greasy groupers (Epinephelus tauvina) supplemented with Ocimum sanctum, Withania somnifera and Myristica fragrans.

Nutrient digestion begins with the actions of (digestive) enzymes in the stomach and continues in the intestine with enzymes secreted by the pancreas, including trypsin, chymotrypsin, amylase and lipase (Nagase, 1964; Moriarty, 1973). Trypsin activity is considered a nutritional conditional indicator of fish, and its secretion is consistent with the activity of the pancreas (Sunde et al., 2001). During the present study, an increase in trypsin activity in the intestine was in line with the results of Yaghoubi et al. (2016), who reported an increase in trypsin level of silvery-black porgy (Sparidentex hasta) juveniles fed a diet containing soy products. Similarly, Kawai and Ikeda (1973) found an increase in the total protease activity of $O$. mykiss fed a high protein diet. It has been reported in several studies that a higher protease activity in the intestine is associated with a higher protein content in the diet (Xiong et al., 2011; Melo et al., 2012).

Amylase is stimulated by glycolytic chains, glycogen, and starch in larval and juvenile fish (Krogdahl et al., 2005). This study observed an enhanced amylase activity in all treatment groups compared with the control. Similar results were reported by Pavasovic et al. (2007) who experimented with animal feeds containing plant-based ingredients and Awad et al. (2012) who reported on O. mykiss supplemented with lupin, mango and stinging nettle. Certainly, amylase was found to increase in O. mykiss fed diets containing increased amounts of dietary plant protein (Kawai and Ikeda, 1973).

Lipase is mainly secreted by the pancreas and exerts a major role in breaking down of fats, especially triacylglycerols, leading to digestion (Awad, 2010). Generally, the experimental groups had a higher lipase activity compared with the control. This result is in line with those of Lopez-Lopez et al. (2005), who observed significant differences in lipase activity in animals fed a sorghum diet compared with those fed red crab meal and sardine meal, and Al-Saraji and Nasir (2013) who reported an increase in lipase activity of C. carpio fed diets containing protein from different sources. In conclusion, the use of $A$. graveolens as an immunostimulant for C. carpio resulted in a significant enhancement of innate immunity, specifically respiratory bursts, lysozyme and MPO activities. Haematological results also showed an increase in $\mathrm{WBC}, \mathrm{RBC}$, Hct and $\mathrm{Hb}$ with plant dietary supplements, and it also resulted in an increase in digestive enzymes, including trypsin, amylase and lipase.

\section{Conclusion}

In the study, Celery has been proved as an effective immunostimulant or antioxidant in higher animals. On the contrary, our results suggest that the methanolic extract of celery has beneficial effects on growth and immune responses when treated at the dose of $0.1 \%$. Further research is needed to examine whether celery methanolic extract is effective for other fish species.

\section{Conflict of Interest}

The authors declare that there is no conflict of interest.

\section{References}

Ahmed, B., Alam, T., Varshney, M. \& Khan, S.A. (2002). Hepatoprotective activity of two plants belonging to the Apiaceae and the Euphorbiaceae family. Journal of Ethnopharmacology, 79(3): 313-316.

Alexander, C.P., Kirubakaran, C.J.W. \& Michael, R.D. (2010). Water soluble fraction of Tinospora cordifolia leaves enhanced the non-specific immune mechanisms and disease resistance in Oreochromis mossambicus. Fish \& Shellfish Immunology, 29(5): 765-772.

Alishahi, M., Ranjbar, M.M., Ghorbanpour, M., Peyghan, R., Mesbah, M. \& Razi J.M. (2010). Effects of dietary Aloe vera on some specific and nonspecific immunity in the common carp (Cyprinus carpio). International Journal of Veterinary Research, 4: 189-195.

Al-Saraji, A.Y.J. \& Nasir, N.A.N. (2013). Effect of different dietary proteins and fats on the digestive enzymes activities in the common carp fingerlings (Cyprinus carpio L.) reared in floating cages. Mesopotamic Journal of Marine Science, 28(2): 121-130.

Awad, E.S. (2010). Studies on plant based dietary supplements for control of Aeromonas hydrophila infections in rainbow trout (Oncorhynchus mykiss walbaum). Ph.D. Thesis. Heriot-Watt University, Scotland, UK.

Awad, E., Austin, D. \& Lyndon, A.R. (2013). Effect of black cumin seed oil (Nigella sativa) and nettle extract (quercetin) on enhancement of immunity in rainbow trout, Oncorhynchus mykiss (walbaum). Aquaculture, 388-391: 193-197.

Awad, E., Austin, B. \& Lyndon, A. (2012). Effect of dietary supplements on digestive enzymes and growth performance of rainbow trout (Oncorhynchus mykiss, Walbaum). Journal of American Science, 8(12): 858-864.

Aydemir, T. \& Becerik, S. (2011). Phenolic content and antioxidant activity of different extracts from Ocimum basilicum, Apium graveolens and Lepidium sativum seeds. Journal of Food Biochemistry, 35(1): 62-79.

Baananou, S., Borgi, W., Mahmoud, A., Boukef, K., Chouchane, N., Aouam, K. \& Boughattas, N.A. (2012). Anti-inflammatory and analgesic activities of Tunisian Apium graveolens L. leaves extracts in rats. Journal of Biologically Active Products from Nature, 2(4): 225-231.

Bilen, S. \& Bulut, M. (2010). Effects of laurel (Laurus nobilis) on the non-specific immune responses of rainbow trout (Oncorhynchus mykiss, walbaum). Journal of Animal and Veterinary Advances, 9(8): 1275-1279. 
Bilen, S., Bulut, M. \& Bilen, A.M. (2011). Immunostimulant effects of Cotinus coggyria on rainbow trout (Oncorhynchus mykiss). Fish \& Shellfish Immunology, 30(2): 451-455.

Bilen, S., Ünal, S. \& Güvensoy, H. (2016). Effects of oyster mushroom (Pleurotus ostreatus) and nettle (Urtica dioica) methanolic extracts on immune responses and resistance to Aeromonas hydrophila in rainbow trout (Oncorhynchus mykiss). Aquaculture, 454: 90-94.

Bilen, S., Yılmaz, S. \& Bilen, A.M. (2013). Influence of tetra (Cotinus coggygria) extract against Vibrio anguillarum infection in koi carp, Cyprinus carpio with reference to haematological and immunological changes. Turkish Journal of Fisheries and Aquatic Sciences, 13(3): 517-522.

Biswas, G., Korenaga, H., Nagamine, R., Kawahara, S., Takeda, S., Tikuchi, Y. \& Sakai, M. (2013). Cytokine mediated immune responses in the Japanese pufferfish (Takifugu rubripes) administered with heat-killed Lactobacillus paracasei spp. paracasei isolated from the Mongolian dairy product. International Journal of Immunopharmacology, 17(2): 358365 .

Blaxhall, P.C. \& Daisley, K.W. (1973). Routine haematological methods for use with fish blood. Journal of Fish Biology, 5: 771-781.

Bradford, M. (1976). A rapid and sensitive method for the quantification of microgram quantities of protein utilizing the principle of protein dye-binding. Analytical Biochemistry, 72(1-2): 248-254.

Cao, J., Chen, J., Wang, J., Wu, X., Li, Y. \& Xie, L. (2013). Tissue distributions of fluoride and its toxicity in the gills of a freshwater teleost, Cyprinus carpio. Aquatic Toxicology, 130131: 68-76.

Caruso, G., Denaro, M. G. \& Genovese, L. (2009). Digestive enzymes in some Teleost species of interest for Mediterranean aquaculture. The Open Fish Science Journal, 2: 74-86.

Choi, S.H., Park, K.H., Yoon, T.J., Kim, J.B., Jang, Y.S. \& Choe, C.H. (2008). Dietary Korean mistletoe enhances cellular nonspecific immune responses and survival of Japanese eel (Anguilla japonica). Fish \& Shellfish Immunology, 24(1): 6773.

Citarasu, T. (2010). Herbal biomedicines: a new opportunity for aquaculture industry. Aquaculture International, 18(3): 403414.

Dalmo, R.A., Ingebrigtsen, K. \& Bøgwald, J. (1997). Non-specific defence mechanisms in fish, with particular reference to the reticuloendothelial system (RES). Journal of Fish Diseases, 20(4): 241-273.

De Pedro, N., Guijarro, A.I., López-Patiño, M.A., Martínez-Álvarez, R. \& Delgado, M.J. (2005). Daily and seasonal variations in haematological and blood biochemical parameters in the tench, Tinca tinca Linnaeus, 1758. Aquaculture Research, 36(12): 1185-1196.

Erlanger, B.F., Kokowsky, N. \& Cohen, W. (1961). The preparation and properties of two new chromogenic substrates of trypsin. Archives of Biochemistry and Biophysics, 95(2): 271-278.
FAO. (2008). Fishery and Aquaculture Statistics. Rome. 57 pp.

Farahi, A., Kasiri, M., Sudagar, M., Soleimani, I. M. \& Zorriehzahra, S.M.J. (2012). Effect of dietary supplementation of Melissa officinalis and Aloe vera on hematological traits, lipid oxidation of carcass and performance in rainbow trout (Oncorhynchus mykiss). Online Journal of Animal and Feed Research, 2(1): 1-5.

Gawlicka, A., Parent, B., Horn, M.H., Ross, N., Opstad, I. \& Torrissen, O.J. (2000). Activity of digestive enzymes in yolk-sac larvae of Atlantic halibut (Hippoglossus hippoglossus): indication of readiness for first feeding. Aquaculture, 184(3-4): 303-314.

Gisbert, E., Giménez, G., Fernández, I., Kotzamanis, Y. \& Estévez, A. (2009). Development of digestive enzymes in common dentex Dentex dentex during early ontogeny. Aquaculture, 287(3-4): 381-387.

Govind, P., Madhuri, S. \& Mandloi, A.K. (2012). Immunostimulant effect of medicinal plants on fish. International Journals of Research Papers, 3(3): 112-114.

Güner, Y., Güleç, F., Ikiz, M. \& Kayaci, A. (2014). General view to Turkish carp (C. carpio) production. Türk Bilimsel Derlemeler Dergisi, 7(2): 66-69.

Haghighi, M. \& Rohani, M.S. (2013). The effects of powdered ginger (Zingiber officinale) on the haematological and immunological parameters of rainbow trout Oncorhynchus mykiss. Journal of Medicinal Plant and Herbal Therapy Research, 1: 8-12.

Haghighi, M., Sharif Rohani, M., Samadi, M., Tavoli, M., Eslami, M. \& Yusefi, R. (2014). Study of effects Aloe vera extract supplemented feed on hematological and immunological indices of rainbow trout (Oncorhynchus mykiss). International Journal of Advanced Biological and Biomedical Research, 2(6): 2143-2154.

Harikrishnan, R., Jin, C.N., Kim, M.C., Kim, J.S., Balasundaram, C. \& Heo, M.S. (2010). Effectiveness and immunomodulation of chemotherapeutants against scuticociliate Philasterides dicentrarchi in olive flounder. Experimental Parasitology, 124(3): 306-314.

Houston, A.H. (1990). Blood and Circulation. In: Schreck, C.B., Moyle, P.B. (Eds.), Methods for Fish Biology. American Fisheries Society, USA, pp. 273-334.

Johnston Jr, R.B. (1978). Oxygen metabolism and the microbicidal activity of macrophages. Federation Proceedings, 37(13): 27592764.

Kawai, S. \& Ikeda, S. (1973). Studies in digestive enzymes of fishes. III. Development of the digestive enzymes of rainbow trout after hatching and the effect of dietary change on the activities of digestive enzymes in the juvenile stage. Bulletin of the Japanese Society for the Science of Fish, 39(7): 265-270.

Kono, T., Hamasuna, S., Korenaga, H., Iizasa, T., Nagamine, R., Ida, T. \& Sakai, M. (2012). The role of neuromedin U during inflammatory response in the common carp. Fish \& Shellfish Immunology, 32(1): 151-160.

Krogdahl, Å., Hemre, G.I. \& Mommsen, T.P. (2005). Carbohydrates in fish nutrition: digestion and absorption in postlarval stages. Aquaculture Nutrition, 11(2): 103-122. 
Kumar, I.V., Chelladurai, G., Veni, T., Peeran, S.S.H. \& Mohanraj, J. (2014). Medicinal plants as immunostimulants for health management in Indian cat fish. Journal of Coastal Life Medicine, 2(6): 426-430.

Lewis, S.M., Bain, B.J. \& Bates, I. (2006). Dacie and Lewis Practical Haematology. 10th ed. Philadelphia: Churchill Livingstone Elsevier. 221 pp.

Li, P., Jia, J., Zhang, D., Xie, J., Xu, X. \& Wei, D. (2014). In vitro and in vivo antioxidant activities of a flavonoid isolated from celery (Apium graveolens L. var. dulce). Food \& Function, 5(1): 5056.

Lopez-Lopez, S., Nolasco, H., Villarreal-Colmenares, H. \& CiveraCerecedo, R. (2005). Digestive enzyme response to supplemental ingredients in practical diets for juvenile freshwater crayfish Cherax quadricarinatus. Aquaculture Nutrition, 11(2): 79-85.

Magnadóttir, B. (2006). Innate immunity of fish (overview). Fish \& Shellfish Immunology, 20(2): 137-151.

Mahdavi, M., Hajimoradloo, A. \& Ghorbani, R. (2013). Effect of Aloe vera extract on growth parameters of common carp (Cyprinus carpio). World Journal of Medical Sciences, 9(1): 55-60.

Melo, J.F.B., Lundstedt, L.M., Moraes, G. \& Inoue, L.A.K.A. (2012). Effect of different concentrations of protein on the digestive system of juvenile silver catfish. Arquivo Brasileiro de Medicina Veterinária e Zootecnia, 64(2): 450-457.

Modaresi, M., Ghalamkari, G. \& Jalalizand, A. (2012). The effect of celery (Apium graveolens) extract on the reproductive hormones in male mice. APCBEE Procedia, 4: 99-104.

Moriarty, D.J.W. (1973). The physiology of digestion of blue-green algae in the cichlid fish, Tilapia nilotica. Journal of Zoology, 171(1): 25-39.

Mostafa, A.A.Z.M., Ahmad, M.H., Mousallamy, A. \& Samir, A. (2009). Effect of using dried Fenugreek seeds as natural feed additives on growth performance, feed utilization, whole-body composition and entropathogenic Aeromonas hydrophilachallenge of monsex Nile tilapia O. niloticus (L) fingerlings. Australian Journal of Basic and Applied Sciences, 3(2): 12341245.

Nagase, G. (1964). Contribution to the physiology of digestion in Tilapia mossambica Peters: digestive enzymes and the effects of diets on their activity. Journal of Comparative Physiology A: Sensory, Neural, and Behavioural Physiology, 49(3): 270-284.

Olvera-Novoa, M.A., Campos, S.G., Sabido, M.G. \& Palacios, C.A.M. (1990). The use of alfalfa leaf protein concentrates as a protein source in diets for tilapia (Oreochromis mossambicus). Aquaculture, 90(3-4): 291-302.

Pakravan, S., Hajimoradloo, A. \& Ghorbani, R. (2012). Effect of dietary willow herb, Epilobium hirsutum extract on growth performance, body composition, haematological parameters and Aeromonas hydrophila challenge on common carp, Cyprinus carpio. Aquaculture Research, 43(6): 861-869.

Pavasovic, A., Anderson, A.J., Mather, P.B. \& Richardson, N.A. (2007). Effect of a variety of animal, plant and single cell-based feed ingredients on diet digestibility and digestive enzyme activity in redclaw crayfish, Cherax quadricarinatus (Von Martens 1868). Aquaculture, 272(1-4): 564-572.

Rao, Y.V., Das, B.K., Jyotyrmayee, P. \& Chakrabarti, R. (2006). Effect of Achyranthes aspera on the immunity and survival of Labeo rohita infected with Aeromonas hydrophila. Fish \& Shellfish Immunology, 20(3): 263-273.

Rodríguez, A., Esteban, M. \& Meseguer, J. (2003). Phagocytosis and peroxidase release by seabream (Sparus aurata L.) leucocytes in response to yeast cells. The Anatomical Record, 272(1): 415423.

Sahoo, P.K., Kumari, J., Mishra, B.K. (2005). Non specific immune responses in juveniles of Indian major carps. Journal of Applied Ichthyology, 21(2): 151-155.

Secombes, C.J. (1996). The nonspecific immune system: Cellular defences In: Iwama, G., Nakanish, T. (eds.), The fish immune system: Organism, pathogens, environment. pp. 63-103.

Secombes, C.J. \& Fletcher, T.C. (1992). The role of phagocytes in the protective mechanisms of fish. Annual Review of Fish Diseases, 2: 53-71.

Seung-Cheol, J.I., Jeong, G., Gwang-Soon, I.M., Lee, S., Yoo, J. \& Takii, K. (2007). Dietary medicinal herbs improve growth performance, fatty acid utilization, and stress recovery of Japanese flounder. Fisheries Science, 73(1): 70-76.

Shirali, S., Erfani Majd, N., Mesbah, M., Reza Seifi, M. (2012). Histological studies of common carp ovarian development during breeding season in Khouzestan province, Iran. World Journal of Fish and Marine Sciences, 4(2): 159-164.

Sivaram, V., Babu, M.M., Immanuel, G., Murugadass, S., Citarasu, T. \& Marian, M.P. (2004). Growth and immune response of juvenile greasy groupers (Epinephelus tauvina) fed with herbal antibacterial active principle supplemented diets against Vibrio harveyi infections. Aquaculture, 237(1-4): 9-20.

Sowbhagya, H.B. (2014). Chemistry, technology, and nutraceutical functions of celery (Apium graveolens L.): an overview. Critical Reviews in Food Science and Nutrition, 54(3): 389-398.

Sunde, J., Taranger, G.L. \& Rungruangsak-Torrissen, K. (2001). Digestive protease activities and free amino acids in white muscle as indicators for feed conversion efficiency and growth rate in Atlantic salmon (Salmo salar L.). Fish Physiology and Biochemistry, 25(4): 335-345.

Tang, J., Cai, J., Liu, R., Wang, J., Lu, Y., Wu, Z. \& Jian, J. (2014). Immunostimulatory effects of artificial feed supplemented with a Chinese herbal mixture on Oreochromis niloticus against Aeromonas hydrophila. Fish \& Shellish Immunology, 39(2): 401-406.

Tekinay, A.A. \& Davies, S.J. (2001). Dietary carbohydrate level influencing feed intake, nutrient utilisation and plasma glucose concentration in the rainbow trout, Oncorhynchus mykiss. Turkish Journal of Veterinary and Animal Sciences, 25: 657-666.

Tokur, B., Ozkütük, S., Atici, E., Ozyurt, G. \& Ozyurt, C.E. (2006). Chemical and sensory quality changes of fish fingers, made from mirror carp (Cyprinus carpio L., 1758), during frozen storage (- 18 C). Food Chemistry, 99(2): 335-341. 
Worthington, C. (1991). Worthington enzyme manual related Biochemical. Freehold, New Jersey, USA.

Xie, J., Liu, B., Zhou, Q., Su, Y., He, Y., Pan, L. Ge, X., Xu, P., 2008. Effects of anthraquinone extract from rhubarb Rheum officinale Bail on the crowding stress response and growth of common carp Cyprinus carpio var. Jian. Aquaculture, 281(14): $5-11$.

Xiong, D. M., Xie, C.X., Zhang, H.J. \& Liu, H.P. (2011). Digestive enzymes along digestive tract of a carnivorous fish Glyptosternum maculatum (Sisoridae, Siluriformes). Journal of Animal Physiology and Animal Nutrition, 95(1): 56-64.

Xu, P., Zhang, X., Wang, X., Li, J., Liu, G., Kuang, Y. \& Zhang, Y. (2014). Genome sequence and genetic diversity of the common carp, Cyprinus carpio. Nature Genetic, 46(11): 12121219.

Yaghoubi, M., Mozanzadeh, M. T., Marammazi, J. G., Safari, O. \& Gisbert, E. (2016). Dietary replacement of fish meal by soy products (soybean meal and isolated soy protein) in silveryblack porgy juveniles (Sparidentex hasta). Aquaculture, 464: 50-59.

Yılmaz, S., Ergün, S. \& Çelik, E.S. (2012). Effects of herbal supplements on growth performance of sea bass (Dicentrarchus labrax): Change in body composition and some blood parameters. Journal of Bioscience and Biotechnology, 1(3): 217-222.

Yin, G., Ardó, L.Á.S.Z.L.Ó., Thompson, K.D., Adams, A., Jeney, Z. \& Jeney, G. (2009). Chinese herbs (Astragalus radix and Ganoderma lucidum) enhance immune response of carp, Cyprinus carpio, and protection against Aeromonas hydrophila. Fish \& Shellfish Immunology, 26(1): 140-145. 